Article

\title{
Agro-Food Residues and Bioethanol Potential: A Study for a Specific Area
}

\author{
Marina Basaglia ${ }^{1}$ D , Massimiliano D'Ambra ${ }^{2}$, Giuseppe Piubello ${ }^{3}$, Veronica Zanconato ${ }^{4}$, Lorenzo Favaro ${ }^{1, *} \mathbb{D}$ \\ and Sergio Casella ${ }^{1}$ \\ 1 DAFNAE-Department of Agronomy Food Natural Resources Animals and Environment, \\ University of Padova, Viale dell’Università 16, 35020 Legnaro, Italy; marina.basaglia@unipd.it (M.B.); \\ sergio.casella@unipd.it (S.C.) \\ 2 Archeo Ed Srl. Via S. Francesco, 35121 Padova, Italy; mdambra@archeoed.it \\ 3 Confcoop Servizi Società Cooperativa-Confcooperative Verona Via Sommacampagna, \\ 37137 Verona, Italy; giuseppe.piubello@gmail.com \\ 4 Collis Veneto Wine Group, Via Cappuccini n.6, 37032 Monteforte d'Alpone, Italy; \\ veronica_zanconato@libero.it \\ * Correspondence: lorenzo.favaro@unipd.it; Tel.: +39-04-9827-2800
}

check for updates

Citation: Basaglia, M.; D'Ambra, M.; Piubello, G.; Zanconato, V.; Favaro, L.; Casella, S. Agro-Food Residues and Bioethanol Potential: A Study for a Specific Area. Processes 2021, 9, 344 https://doi.org/10.3390/pr9020344

Academic Editors: Antonio

D. Moreno and Paloma Manzanares

Received: 10 January 2021

Accepted: 11 February 2021

Published: 13 February 2021

Publisher's Note: MDPI stays neutra with regard to jurisdictional claims in published maps and institutional affiliations.

Copyright: (C) 2021 by the authors Licensee MDPI, Basel, Switzerland. This article is an open access article distributed under the terms and conditions of the Creative Commons Attribution (CC BY) license (https:// creativecommons.org/licenses/by/ $4.0 /)$

\begin{abstract}
Bioethanol obtained from agro-food wastes could contribute to decrease the dependency on fossil resources, reduce the impact of fossil fuels on the environment, and mitigate the food versus fuel debate. This study is aimed to investigate the availability of residual inexpensive agro-food biomasses that could feed a second-generation bioethanol plant located in a specific area of North Eastern Italy. After the identification of all crops in the area, more than 40 agro-food residues were analyzed for their availability and compositions in terms of water, polysaccharides, and sugars potentially convertible into bioethanol. 574,166 Mg of residual wet lignocellulosic biomass corresponding to $297,325 \mathrm{Mg}$ of dry material were found available for bioethanol conversion. The most promising substrates were wheat straw and vine shoots. Based on the chemical composition of residues, the potential attainable ethanol was determined. Theoretical potential ethanol production was estimated at nearly $72,000 \mathrm{Mg}$ per year. This quantity extensively exceeds the minimum yearly capacity of a sustainable bioethanol plant previously identified as around 50,000 Mg of ethanol. Taken together, these results demonstrate that, in the analyzed area, agro-food residues are available in an amount that could sustain bioethanol production in a specific and restricted district. Techno-economical evaluations are in progress to assess the actual feasibility of installing a second generation bioethanol production plant in the area of interest.
\end{abstract}

Keywords: bioethanol; residual biomass; agricultural waste streams; yeast; second-generation bioethanol plant; wheat straw; vine shoots

\section{Introduction}

Concern for the increase in the price of oil, the decline in fossil fuel reserves, and global warming have encouraged the search for new sources of energy [1].

Within the new production system of the bioeconomy, energy, materials, and chemical products could be obtained from renewable biological resources such as biomasses [1-8]. Biomasses are a resource of great interest due to their heterogeneity and versatility, thus many sectors of the agroforestry, industry, and services could be involved [8,9]. In this scenario, biomass utilization can effectively contribute to reduce the dependence on fossil resources, limit the impact on the environment, and mitigate climate change.

Biofuels have received considerable attention from the scientific community and the industrial world on both a global and a local scale as direct substitutes for fossil fuels in the transport sector. Despite that their costs are still high, the use of biofuels is increasing worldwide thanks to the support provided by policy measures, mainly aimed to increase 
the quality of the environment. In the European Union, within 2030, each Member State should ensure that the share of energy from renewable sources is consistent with a target of at least a $32 \%$ share of energy from renewable sources in the community's gross final consumption of energy. To achieve the targets, each Member State shall promote and encourage energy efficiency and energy saving as reported in the Directive (EU) 2018/2001 of the European Parliament and of the Council of 11 December 2018 on the promotion of the use of energy from renewable sources [10].

Bioethanol guarantees a lower environmental impact, compared to that caused by fossil fuels in terms of atmospheric emissions of polluting compounds and greenhouse gasses [11-13]. According to current knowledge, bioethanol is industrially produced from biomass traditionally used for food, rich in sugars or starch (first-generation bioethanol) such as corn (Zea mays), sugarcane (Saccharum officinalis), and sugar beet (Beta vulgaris) in the US, China, Canada, Brasil, and France. Other small productions are reported in Canada from wheat (Triticum aestivum) and in Thailand from cassava (Manihot esculenta) [14-16]. Unfortunately, the competition with existing food productions causes a contrast between food-for-food and food-for-fuel with a strong impact on food prices, mainly affecting poor people in the global South [17-19]. These situations lead the scientific community to look for new solutions towards the use of inexpensive raw materials from plants, specifically cropped in marginal lands, or alternatively cheap waste materials deriving from agricultural activities or industrial food productions.

The search for cheap waste feedstocks, rich in fermentable substrates and noncompeting with food, is, indeed, crucial towards large-scale second-generation ethanol production $[20,21]$. The discarding of waste agro-food biomasses can be costly and sometimes even a risk for the environment related to their spreading in the field; therefore the transformation of lignocellulosic residual biomasses into value-added products can lead to a reduction in removal costs and offer integration of farmers' income. Unfortunately, these potentially convertible biomasses are heterogeneous in composition and origin and consequently require the application of chemical-physical treatments aimed at hydrolyzing plant polysaccharides into sugars to be fermented by microorganisms $[7,15,22,23]$. These procedures are strongly dependent on the chemical and physical nature of the substrates [24-26]. Many studies have been developed in the past about the possible exploitation of specific agri-cultural biomasses or wastes from industrial processes at the national or world level (see as examples: [21,27-30]), and in general, the amounts of agricultural wastes in Europe could be considerable [31-33]. However, a detailed analysis reporting the composition and the real availability of these complex materials is not available. Moreover, biomass handling and transportation can strongly contribute to exploitation costs suggesting that transporting biomass to a large, but far, processing plant is not economically worthwhile. Consequently, the most suitable processes to ensure both the complete exploitation of the agricultural byproducts and the economic viability towards the construction of secondgeneration bioethanol production plants, has yet to be defined.

Indeed, studies including the potential of agro-food wastes as a feedstock for bioethanol use, have not been performed so far at a local scale level. Thus, for the first time, this research aimed to estimate, in a defined region, the potential of supplying selected residual biomass for energy use, thus filling the gap in knowledge on the potential yield of agri-cultural wastes as bioethanol feedstocks. This work indeed performed a capillary availability estimation of the inexpensive wastes resulting from the agricultural activity and their potential bioethanol yields in a specific territory of the Province of Verona, in the Veneto Region. The main objective was to collect data necessary for future technical and economic assessments aimed to design an industrial plant for second-generation bioethanol located in this specific zone. 


\section{Materials and Methods}

\subsection{Sampling, Preparation, and Analyses of Biomasses from Agricultural Residues}

The evaluated area was located in the Po' Valley, mainly in the Province of Verona (Italy) having the center in the Municipality of Soave (Latitude: $45^{\circ} 25^{\prime} 10^{\prime \prime} \mathrm{N}$, Longitude: $\left.11^{\circ} 14^{\prime} 45^{\prime \prime} \mathrm{E}\right)$ and extending for approximately $11,300 \mathrm{Km}^{2}$. In this district, data on the cultivated area were acquired from AVEPA (Agenzia Veneta per i Pagamenti in Agricoltura), and all crops present in the territory were determined.

To estimate the type, the real amount, and the existing disposal and valorization strategies of wastes deriving from each crop in this specific area, 3-5 farmers for each crop were interviewed and around 250 surveys were conducted. Although all crops were recorded, only residues produced in significant amounts and/or not already utilized by farmers were taken into consideration for subsequent analyses. Selected wastes included also fruits and vegetables discharged by growers due to poor quality and some byproducts from the food-industry present in the territory.

Samples of about $10 \mathrm{Kg}$ were obtained from at least 3 different producers/farmers and mixed. Residues from fruits were freeze-dried while those from vegetables were predried at $60^{\circ} \mathrm{C}$ in a forced-air oven for $48 \mathrm{~h}$, then ground in a hammer mill through a $1.0 \mathrm{~mm}$ sieve. The composition in terms of residual water, ash, starch, hemicellulose, cellulose, lignin, and protein of each sample was determined according to international standard methods: total ash and moisture were obtained by calcinating the samples at $550{ }^{\circ} \mathrm{C}$ and drying them in a forced oven at $103^{\circ} \mathrm{C}$ respectively, according to the AOAC methods [34] (method 942.05 and 934.01). Total nitrogen was determined by the Kjeldahl method, followed by the protein calculation using the general factor of 6.25 [34] (Method 981.10). Cellulose, hemicellulose, and lignin were estimated according to [35]. Starch was determined as described in [36]. Soluble sugar analyses (glucose, fructose, sucrose, xylose, rhamnose, arabinose, and cellobiose), were performed using the methods of [37]: briefly, when necessary, pits were removed and samples were homogenized using a mixer. Samples of $10 \mathrm{~g}$ were resuspended in $50 \mathrm{~mL}$ of deionized water for 30 minutes at room temperature. After centrifugation at $12,000 \times g$ for $7 \mathrm{~min}$ at $10^{\circ} \mathrm{C}$, supernatants were filtered using a $0.45 \mu \mathrm{m}$ acetate cellulose filter and analyzed by HPAEC-PAD (High-Performance Anion-Exchange Chromatography with Pulsed Amperometric Detection) using a PA1 column and $\mathrm{NaOH}(1 \mathrm{mM})$ as mobile phase [36].

All analyses were performed in triplicate and results are presented as average values with standard deviations below $5 \%$.

\subsection{Bioethanol Potential from Residual Agro-Food Wastes}

Bioethanol potential of the residues was assessed considering the bioethanol that can be produced after the fermentation of their simple sugars as well as from starch, cellulose, and hemicellulose after pretreatment and/or enzymatic saccharification. Therefore, theoretical ethanol yield from each waste considered in this study was calculated based on its starch, cellulose, hemicellulose, and fermentable sugars contents as previously described $[38,39]$. In short, bioethanol yield from biomasses was estimated as the amount of ethanol potentially obtainable from the fermentation of free available sugars and hydrolysates of starch, cellulose, and hemicellulose, whose hydrolysis yields were assumed to be $91 \%, 81 \%$ and $96 \%$ respectively. Stoichiometric ethanol fermentation yields of monosaccharides were $92.5 \%$ for glucose, fructose, and sucrose and $86 \%$ for xylose. Ethanol recovery yields after distillation were hypothesized to be $99.5 \%$.

The efficiency yields previously proposed $[38,39]$ were recently confirmed from a cluster of lignocellulosic [40-43] and starchy waste streams [36,44-46] considered in this project. To validate the ethanol fermentation yields values also from residues rich in simple sugars, few sugary byproducts were selected and fermented by an efficient Saccharomyces cerevisiae strain as described below. 


\subsection{Fermentation of Sugar-Rich Waste Streams}

Plums and peaches waste streams obtained from Quargentan SpA (Terrossa di Roncà, Verona, Italy) have been used as feedstock for the fermentation by S. cerevisiae MEL2 a highly efficient yeast strain [47]. Precultures of S. cerevisiae MEL2 grown to early stationary phase in Yeast Nitrogen Base (YNB) without amino acids were adopted as inoculum. Cells, collected, centrifuged ( $5400 \times g$ for $5 \mathrm{~min})$, and washed twice with sterile distilled water, were used to inoculate $50 \mathrm{~mL}$ YNB without amino acids broth to an initial Optical Density $(600 \mathrm{~nm})$ of 1.0. Small-scale fermentations were performed in $55 \mathrm{~mL}$ glass serum bottles as described by [48], with rubber stoppers ensuring oxygen-limited conditions. The serum bottles contained $50 \mathrm{~mL}$ YNB without amino acids broth and 10\% dw/v of freeze-dried byproduct. Ampicillin $(100 \mu \mathrm{g} / \mathrm{mL})$ and streptomycin $(100 \mu \mathrm{g} / \mathrm{mL})$ were added to limit bacterial growth. Serum bottles were incubated at $30^{\circ} \mathrm{C}$ on a magnetic stirrer and samples, obtained before and during fermentation, were analyzed for simple sugars (glucose, sucrose, fructose, arabinose, cellobiose, xylose), ethanol, glycerol, and acetic acid content using HPAEC-PAD, as described in [48]. The ethanol yield, (g of ethanol/g of used glucose equivalent) was calculated on the basis of the amount of glucose/fructose/sucrose utilized during the fermentation and compared to the maximum theoretical yield of $0.51 \mathrm{~g}$ of ethanol/g of utilized glucose equivalent.

\section{Results and Discussion}

\subsection{Sampling and Biomass Availability}

The main objective of this work was to assess the availability of low-cost lignocellulosic and sugary materials resulting from agricultural activities, including fruits and vegetable wastes from processing industries, in a specific area of North Italy. The evaluated district, indicated in Figure 1, has a radius of $60 \mathrm{~km}$ with the city of Soave in the center and a total area of about 1,130,400 ha, partially including the province of Verona and, to less extent, those of Padova, Vicenza, and Rovigo.

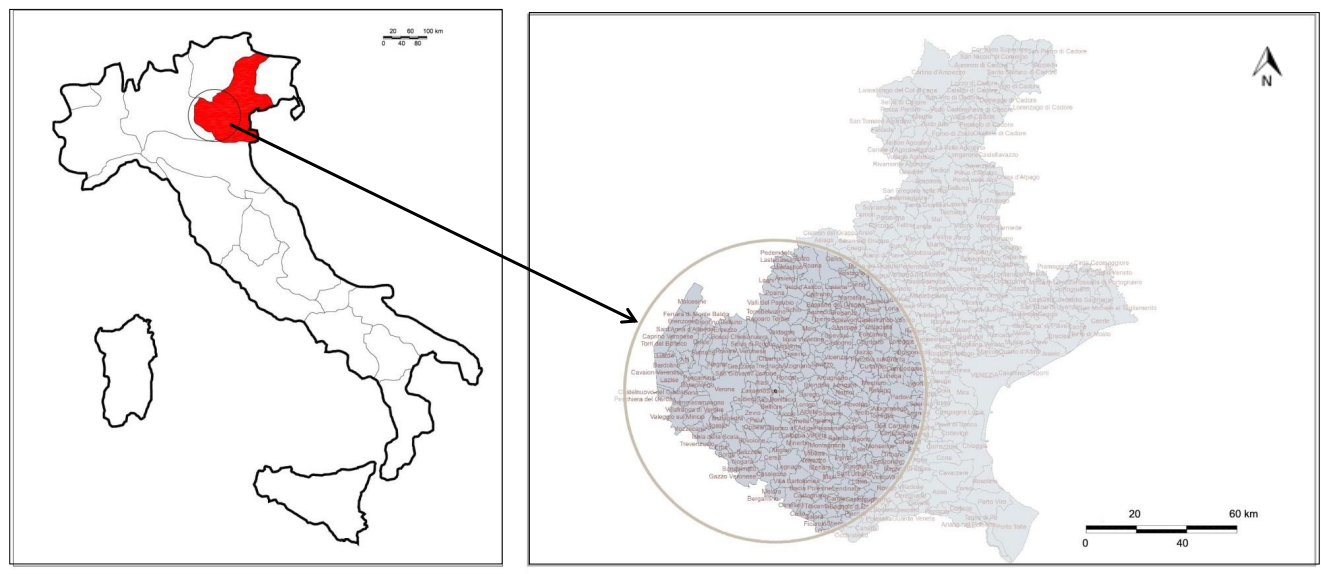

Figure 1. Map of the evaluated geographical area considered in this study.

The area was specifically selected because of being a model district within the Northern Italy intensive agriculture context. As reported by AVEPA, a share of approximately 226,000 ha is farmed: $52.28 \%$ is cultivated with extensive crops (mainly corn, wheat, and soybean), $14.74 \%$ with vineyard, $7.06 \%$ with orchards, $4.09 \%$ with horticultural products, and $1.10 \%$ with olive groves (Table 1 ). The remaining $19.73 \%$ is used as a nursery or cropped with pasture meadows, poplar, and woody plants, or managed as set-aside as established by the EU that provides economic support to the farmers. 
Table 1. Main crops and hectares farmed in the sampled area. In brackets, the percentage of total cropped hectares is specified. Data were obtained from AVEPA.

\begin{tabular}{cc}
\hline Crops & Hectares \\
\hline Extensive cultures & $120,623(52.28 \%)$ \\
Vineyard & $33,363(14.74 \%)$ \\
Horchards & $15,995(7.06 \%)$ \\
Vegetables & $9268(4.09 \%)$ \\
Olive groves & $2491(1.10 \%)$ \\
Others & $44,671(19.73 \%)$ \\
\hline Total hectares & $\mathbf{2 2 6 , 4 1 1}$ \\
\hline
\end{tabular}

More than 80 different cultures were detected and a complete list of cropped plants and related surfaces is available in the Supplementary materials (Table S1). The most extensive crop in the analyzed area is corn (around 61,000 ha), which generally yields large quantities of residues. A great share of these materials is used as fodder, litter, or solid fuel [4], while a portion remains on the ground after harvesting and is landfilled, thus contributing to the maintenance of the soil organic carbon content of the soil, essential for the conservation of the fertility [49-51]. Furthermore, considering that large amounts of corn are feeding biogas production plants or stocked as ensilage, only $20-25 \%$ of the corn completes the crop cycle with the grain harvesting and the production of residual biomass [51]. Therefore, in this specific area, corn wastes have already a commercial value. For these reasons, although corn is the most extensively cropped plant, it was not taken into consideration in the present work. Similarly, the amount of wheat straw considered in this study was only 100,000 Mg; in fact, for each hectare cropped with wheat, around $7 \mathrm{Mg}$ of wheat straw could be potentially harvestested. Therefore, $214,000 \mathrm{Mg}$ of wheat straw are theoretically available and could be sold to farmers for animal feed. Since livestock farms in the district are in low number, a considerable amount of straw is left on the field.

The majority of the wastes considered in this research and reported in Table 2 and Table S2 are not commercially relevant. Furthermore, they are mostly left in the field or burned (i.e., vegetables and vine shoots) or need disposal costs for the farmers (i.e., fruits and straw). Even excluding corn and a part of wheat straw, the results of the study highlight that relatively large amounts of residual biomass are available for their exploitation for energetic purposes (Table 2 and Table S2. Specifically, 574,166 Mg of residual wet lignocellulosic biomass (297,325 $t$ of dry matter) originating from agricultural activities or industrial processing of fruits and vegetables are produced yearly. Considerable quantities $428,350 \mathrm{Mg}$ (wet wastes), corresponding to a dry weight of $259,769 \mathrm{Mg}$, originate mainly from wheat $(100,000 \mathrm{Mg})$, tobacco $(51,000 \mathrm{Mg})$, vineyard $(100,000 \mathrm{Mg}$ vine shoots, $68,000 \mathrm{Mg}$ grape marcs, $12,500 \mathrm{Mg}$ of grape stalks), apple (32,500 Mg), soy (43,850 Mg soy straw) and sugar beet (33,000 Mg); further residual biomasses from other crops or food transformation processes were found in lower amounts although their total mass was up to $145,816 \mathrm{Mg}$ (wet matter) equivalent to a dry matter of $37,556 \mathrm{Mg}$. Overall, as reported in Table 2 and detailed in Table S2, $31.44 \%$ and $27.73 \%$ of residues originated from vineyards $(100,000 \mathrm{Mg}$ from vine shoots, 68,000 from grape marcs, 12,500 from grape stalks) and straws (100,000 Mg from wheat, $8000 \mathrm{Mg}$ from spring barley, 43,850 Mg from soy bean, and $7400 \mathrm{Mg}$ from rice), respectively. Fruit and vegetable wastes amounted for $10.63 \%$ and $12.84 \%$. 
Table 2. Expected amounts (wet and dry) of residues from crops grown in the analyzed area and producing high amounts of wastes. Results of chemical analyses are the means of three replicates. Amounts of agricultural residues and main polysaccharides on a dry matter basis were estimated based on the information obtained from the farmers and the performed chemical analyses, respectively.

\begin{tabular}{|c|c|c|c|c|c|}
\hline Residue & $\begin{array}{l}\text { Wet Waste } \\
(\mathrm{Mg})\end{array}$ & $\begin{array}{l}\text { Dry Waste } \\
(\mathrm{Mg})\end{array}$ & $\begin{array}{l}\text { Starch } \\
(\mathbf{M g})\end{array}$ & $\begin{array}{l}\text { Cellulose } \\
\text { (Mg) }\end{array}$ & $\begin{array}{l}\text { Hemicellulose } \\
\text { (Mg) }\end{array}$ \\
\hline Wheat straw & 100,000 & 91,371 & nd & 38,205 & 27,595 \\
\hline Tobacco * & 51,000 & 10,143 & nd & 3087 & 1455 \\
\hline Vine shoots $* *$ & 50,000 & 43,936 & 397 & 17,684 & 8956 \\
\hline Vine shoots $^{+}$ & 50,000 & 39,594 & 358 & 16,528 & 7909 \\
\hline White grape marc $¥$ & 46,000 & 19,018 & 180 & 2330 & 1604 \\
\hline Soy straw & 43,850 & 37,349 & nd & 14,666 & 5695 \\
\hline Sugar beet $^{\circ}$ & 33,000 & 6893 & nd & 918 & 1130 \\
\hline Apples & 32,500 & 3617 & nd & 218 & 112 \\
\hline Red grape marc \# & 22,000 & 7847 & 73 & 1151 & 969 \\
\hline Others $* * * *$ & 145,816 & 37,556 & 1,786 & 9441 & 6602 \\
\hline TOTAL (Mg) & 574,166 & 297,325 & 2794 & 104,228 & 61,487 \\
\hline $\begin{array}{c}\% \text { of the waste stream from } \\
\text { title }\end{array}$ & $\begin{array}{l}\text { Fruits } \\
10.63\end{array}$ & $\begin{array}{c}\text { Vegetables } \S \S \S \\
12.84\end{array}$ & $\begin{array}{c}\text { Vineyards }^{a} \\
31.44\end{array}$ & $\begin{array}{l}\text { Straws } \\
26 * 4 \\
26.44\end{array}$ & \\
\hline
\end{tabular}

*: Nicotiana tabacum; ${ }^{* *}$ : cv Garganega; ${ }^{+}$: cv Valpolicella; ${ }^{*}:$ nonfermented and containing stalks; ${ }^{\circ}:$ leaves and crowns; ${ }^{\#}$ : fermented; nd: not detected; $\$ \S \S$ : plants and fruits; ${ }^{* * *}$ : straw from wheat, soy and barley; ${ }^{a}$ : grape marcs, vine shoots, grape stalks; ${ }^{* * * *}$ : all other evaluated residues are reported in Table S2.

The interviews collected in this study indicated that the highest availability of materials was between March and October-November, although significant amounts could also be obtainable during the winter months. Nevertheless, it is important to note that vegetable and fruits, available from spring to autumn months, contribute to $10.63 \%$ and $12.84 \%$ of the wet biomasses respectively (Table 2), they have high water contents and thus might be quickly processed to avoid microbial proliferation. On the other hand, $26.44 \%$ of wet residues derive from straws and $17.4 \%$ from vine shoots (100,000 Mg over 574,166 Mg wet). These materials have high dry weigh (with values ranging from $79.19 \%$ for vine shoots to $91.51 \%$ for spring barley; Table 2 and Table S2); thus, they could be easily stored and used in the bioethanol plant along the year when the contribution of vegetable and fruits is strongly reduced.

\subsection{Chemical Analyses of Biomasses}

Since the chemical composition of the feedstock is crucial to select the most appropriate pretreatment and saccharification technologies [52-54], this work specifically focused on the detailed chemical analysis of all the byproducts, taking into consideration dry weight, free sugars, cellulose, hemicellulose, lignin, and starch contents (Tables 2 and 3 and Tables S2 and S3).

Free sugars were found available in all tested substrates at different concentrations. As expected, fruit residues were the richest in sucrose, glucose, and fructose. For instance, in the case of plums, up to $91 \mathrm{Kg}$ of simple sugars per tonne of wet residue were detected (Table 3 and Table S3). Additionally, all residues contain only traces of simple sugars not fermentable by $S$. cerevisiae, such as xylose, rhamnose, arabinose, and cellobiose (data not shown). Overall, considering also the sugar content of all the tested byproducts, the total yearly amount of fermentable sugars available within the geographical district under study amounted to more than $11,500 \mathrm{Mg}$ (Table S3). 
Table 3. Residues containing the higher amounts of sucrose, glucose, and fructose, and total yearly expected quantities of fermentable sugars. Results are reported as amounts per wet weight or, when reported, dry weight of the feedstock.

\begin{tabular}{|c|c|c|c|c|c|c|c|}
\hline RESIDUE & $\begin{array}{c}\text { Total } \\
\text { Fermentable } \\
\text { Sugars } \\
\text { (kg/Mg of Wet } \\
\text { Residue) }\end{array}$ & $\begin{array}{c}\text { Total } \\
\text { Fermentable } \\
\text { Sugars } \\
\text { (kgMg of Dry } \\
\text { Residue) }\end{array}$ & $\begin{array}{c}\text { Sucrose } \\
(\mathrm{g} / \mathrm{kg})\end{array}$ & $\begin{array}{c}\text { Glucose } \\
(\mathrm{g} / \mathrm{kg})\end{array}$ & $\begin{array}{c}\text { Fructose } \\
(\mathrm{g} / \mathrm{kg})\end{array}$ & $\begin{array}{c}\text { Total } \\
\text { Fermentable } \\
\text { Sugars * (Mg) }\end{array}$ & $\begin{array}{l}\text { Amount of } \\
\text { Dry Residue } \\
\text { (Mg) }\end{array}$ \\
\hline Plums & 91.60 & 629.75 & 1.69 & 59.74 & 30.19 & 73.29 & 116.00 \\
\hline Apples & 75.16 & 675.30 & 5.70 & 21.63 & 47.83 & 2.442 .83 & 3.62 \\
\hline Apricot & 71.30 & 436.36 & 7.42 & 37.72 & 26.20 & 23.18 & 53.00 \\
\hline White grape marc $\stackrel{ }{¥}$ & 69.88 & 169.04 & 2.17 & 38.13 & 29.58 & 3.214 .85 & 19.02 \\
\hline Peaches (fruit, wastes) & 54.79 & 534.80 & 22.71 & 16.88 & 15.20 & 208.22 & 389.00 \\
\hline Rice middlings & 43.43 & 49.04 & 16.79 & 16.83 & 9.82 & 33.45 & 682.00 \\
\hline Onion & 40.62 & 365.27 & 6.07 & 17.60 & 16.94 & 668.17 & 1.83 \\
\hline Grape stalks & 36.90 & 146.77 & 0.00 & 18.19 & 18.71 & 461.35 & 3.14 \\
\hline Chinese cabbage $^{£}$ & 33.88 & 441.45 & 1.31 & 18.96 & 13.61 & 355.78 & 806.00 \\
\hline Aubergines (fruit) & 29.70 & 363.35 & 1.38 & 14.63 & 13.72 & 2.97 & 100.00 \\
\hline Potato & 24.30 & 293.46 & 0.70 & 12.24 & 11.40 & 316.33 & 1.08 \\
\hline Mixed fruits and vegetables & 21.71 & 220.09 & 0.81 & 8.93 & 11.97 & 358.28 & 1.63 \\
\hline
\end{tabular}

${ }^{\ddagger}$ : non fermented and containing stalks; ${ }^{£}$ : Brassica pekinensis; *: Total fermentable sugars in the area were calculated based on the concentration of total fermentable sugars of each substrate and the amounts of residues available in the area of interest as reported in Table S2.

The fruity wastes are particularly interesting feedstocks because they could be directly processed and converted into bioethanol without any pretreatment. Moreover, fruit wastes, together with grape marcs, although containing high volumes of water, are available in huge amounts, reaching up to $112.000 \mathrm{Mg}$ of wet material (68,000 Mg grape marcs, $32,500 \mathrm{Mg}$ from apples, 11,725 Mg from melon, peaches, plums, and apricot) corresponding to a dry weight of around $31,000 \mathrm{Mg}$ in the same area (Table S2).

This amount could strongly increase in case of the low price of fruits or if particularly adverse weather conditions negatively affect the commercial quality of the products and make them unsuitable for the market. For example, apples are cropped in the analyzed area in approximately 5200 hectares (Table S1), and, considering a yield of about $50 \mathrm{t}$ per hectare, the total apple production could be estimated as $260,000 \mathrm{Mg}$, usually retailed as fresh. From the interviews to the farmers, it emerged that, during processing and preparation for the market, apple wastes can amount up to 39,000 Mg (wet weight) (nearly 15\% of the local production) and are generally discharged.

Considering now the polysaccharides content of the byproducts, starch is one of the most promising for the production of ethanol. It is contained at significant percentages only in wastes deriving from rice and potato (up to 84.61 in discolored rice, and $49.18 \%$ of dry weight in potato, Table S2). These values are in accordance with starch contents recently described for rice $[36,44]$ and potato $[55,56]$ residues. The cost-effective conversion of starchy residues into ethanol needs the utilization of industrial amylases. As an alternative, the search for a starch hydrolyzing yeast as a unique organism, able to obtain liquefaction, hydrolysis, and fermentation (Consolidated bioprocessing, CBP), has to be pursued $[36,45,46]$. The technology for starch bioethanol is mature and well established, but although promising, only 15,000 Mg (wet weight) of starch-rich potato and rice waste streams are available in the selected area. As such, they could contribute only in a limited portion as feedstocks for a bioethanol plant (Table S2).

As expected, most of the wastes had relevant amounts of cellulose, but unluckily, S. cerevisiae, employed for the conversion of the sugar into ethanol, cannot directly ferment cellulosic feedstocks into ethanol. Moreover, the polysaccharide is embedded in a recalcitrant and complex matrix and, therefore, the fermentation process is difficult and costly [24,57]. As reported in Table S2, the highest cellulose contents, ranging from $39.27 \%$ to $44.86 \%$ of dry matter, were detected in barley, wheat and soy straw, and vine shoots. These values are in agreement with those obtained by other authors [58-60]. These substrates have also a high dry matter content (from $79.19 \%$ to $91.51 \%$ ) and are available 
in large quantities (around 250,000 Mg dry weight). Vine shoots and wheat straw are produced in considerable volumes (each around 100,000 $\mathrm{Mg}$ as wet byproduct, Table 2) in the area, particularly renowned for the production of wine and wheat.

Most of the horticultural substrates, such as cabbage, zucchini, or those obtained from processing chickory, a typical culture of this area, are available in remarkable quantities. However, although containing interesting amounts of cellulose (13-18\%), these residues had very low dry weight (Table S2). This aspect might represent a barrier to their exploitation in a possible bioethanol production plant, due both to their large water content and to the logistics of collecting and transporting these byproducts to the plant.

It is also important to mention the abundance of hemicellulose with more than $61,000 \mathrm{t}$ yearly available (Table 2). Once again, the substrates richest in hemicellulose are straws and shoots, with percentages ranging from 15.25 to $33.16 \%$ of dry matter, although the polymer is present in considerable amounts in many residues (Table S2). Hemicellulose could be also hydrolyzed into monomers by the available technologies, but special yeast strains such as Pichia pastoris, able to convert the deriving pentoses into ethanol, are required [61]. The most used microorganism for industrial ethanol production is S. cerevisiae, highly fermenting exoses (free or resulting from cellulose hydrolysis) but unable to convert xylose and arabinose originating after hemicellulose saccharification. The efficient fermentation of pentose sugars is a major technical bottleneck for commercial second-generation bioethanol production; the search for natural new strains having the ability to proficiently ferment all kinds of sugars and tolerate inhibitors was not successful [61,62]. Furthermore, although genetically engineered yeast of $S$. cerevisiae able to convert pentoses have been already obtained at lab scale [63-66], industrial strains still show low productivity and are not available yet for large scale bioethanol plants [67]. However, although so far the technologies are not completely established, xylose could be also converted into alcohol on an industrial scale. Therefore, xylose has been considered in the estimation of potential bioethanol yield.

Finally, all residues contain lignin that can reach values up to $33 \%$ of the dry weight (Table S2). Unfortunately, lignin is nonfermentable by microorganisms, insoluble, and recalcitrant to biochemical and chemical treatments. Therefore, lignin cannot be considered for bioethanol production but it could be utilized for heat or electricity production contributing to the sustainability of the entire process $[21,26,68,69]$.

\subsection{Potential Bioethanol Yield}

Based on the fermentable sugars, cellulose, hemicellulose, and starch contents, the potential bioethanol was figured out for each biomass, as described in Materials and Methods using the yields proposed by Spatari et al. [38] and Godin and colleagues [39]. These values were recently confirmed in literature from a cluster of lignocellulosic [40-43] and starchy waste steams $[36,44,45]$ considered in this project. On the contrary, no papers dealing with sugary byproducts available in the geographical district here selected have been recently published. Therefore, two sugar-rich waste streams, namely plums and peaches byproducts from fruit processing industries located within the area of interest, have been efficiently fermented by S. cerevisiae MEL2 (data not shown). Ethanol yields from glucose, sucrose, and fructose were found to be $92.5 \%, 92.8 \%$ and $93.0 \%$, respectively, of the maximum theoretical, thus confirming the simple sugar-to-ethanol efficiencies proposed by Spatari et al. [38] and Godin and colleagues [39] and applied in this work to estimate the bioethanol potential from waste materials.

Figure 2 reports the potential bioethanol $(\mathrm{kg}$ per $\mathrm{Mg})$ of the different investigated biomasses. Yearly potential ethanol attainable $(\mathrm{Mg})$ from starch, cellulose, hemicellulose, and fermentable sugars for the entire quantity of each residue in the analyzed area is reported in Figure 3. The detailed characterization of both bioethanol potential per tonne of residue and yearly bioethanol potential is available in Tables S4 and S5. 


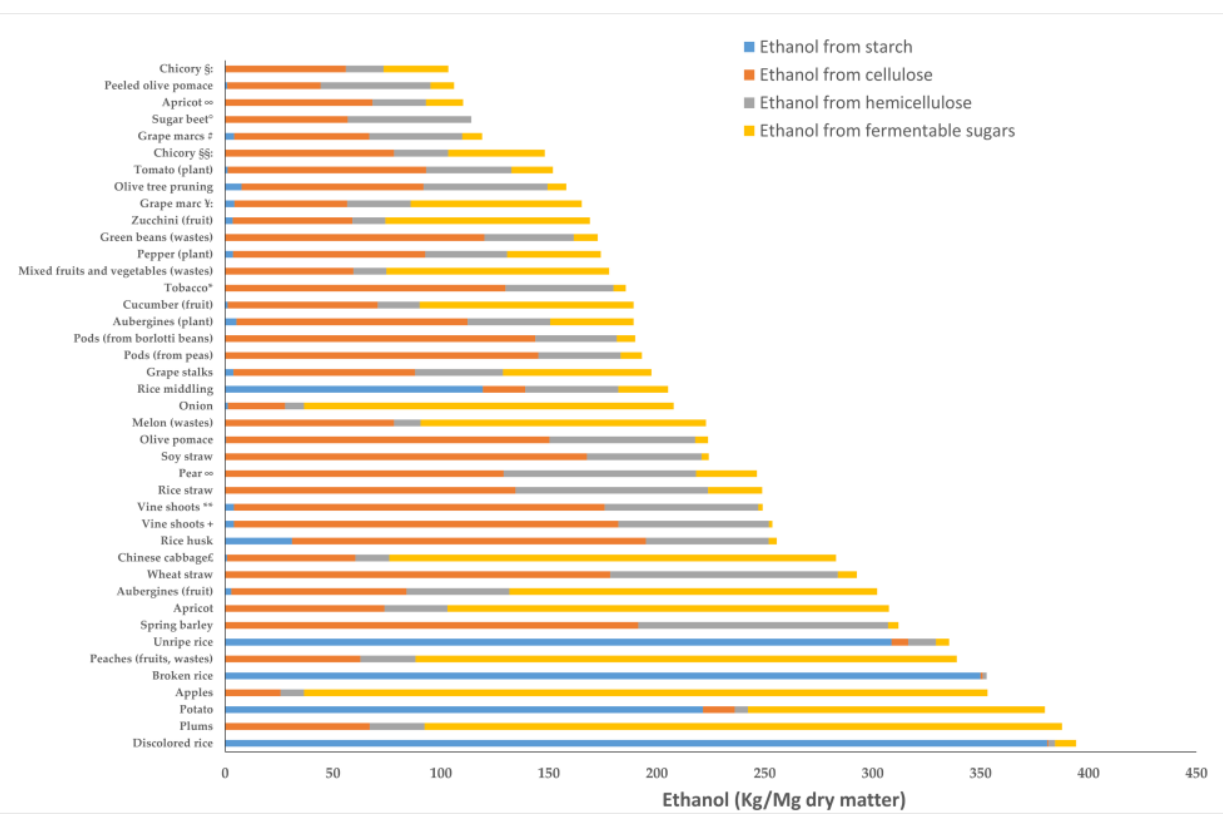

Figure 2. Potential ethanol yield $(\mathrm{kg})$ per $\mathrm{Mg}$ of dry residue from starch, cellulose, hemicellulose, and fermentable sugars. *: Nicotiana tabacum; ${ }^{* *}$ : cv Garganega; +: cv Valpolicella; ¥: nonfermented and containing stalks; ${ }^{\circ}$ : leaves and crowns; \#: fermented; $£$ : Brassica pekinensis; §: leaves and wastes; §§: water and leaves; $\infty$ : from processing industry.

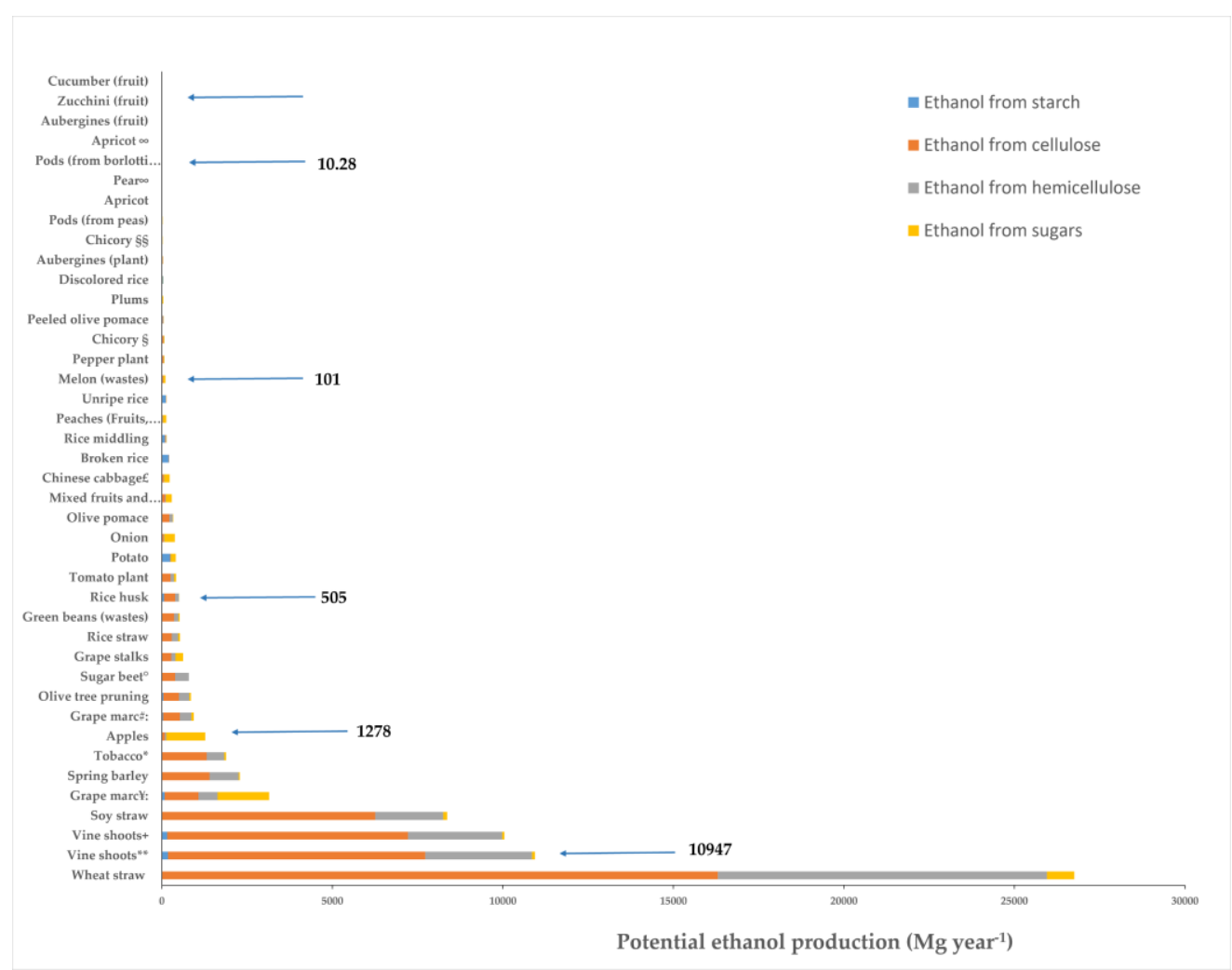

Figure 3. Yearly potential ethanol $(\mathrm{Mg})$ obtainable from simple sugars, starch, cellulose, hemicellulose available in all analyzed residues. Arrows indicate the values of ethanol for selected byproducts. *: Nicotiana tabacum; **: cv Garganega; +: cv Valpolicella; ¥: nonfermented and containing stalks; ${ }^{\circ}$ l leaves and crowns; \#: fermented; $€$ : Brassica pekinensis; §: leaves and wastes; $\S \S$ : water and leaves; $\infty$ : from processing industry. 
The byproducts showed variable potentialities (Figure 2 and Table S4) in terms of ethanol yield per megagram of residue or cropped hectare. Discolored, broken, and unripe rice exhibited among the highest bioethanol potential values, with nearly 394, 352, and $335 \mathrm{~kg}$ of ethanol per megagram of dry matter (Figure 2). This is mostly due to their high starch content (Table S2). Plums, apples, and potatoes had comparable ethanol potentials because of their high simple sugars and, again, starch concentrations, respectively. Lower, but still considerable, values (from 224 to $292 \mathrm{~kg}$ ethanol/Mg) were found for vine shoots and straws (from wheat, rice, and soy) whereas horticultural residues, such as pods, aubergines, cucumber, zucchini, pepper, and tomato plants, have potential ethanol yields below $200 \mathrm{~kg} / \mathrm{Mg}$.

Overall, as stated above, the starchy wastes from rice and potatoes, as well as fruits, rich in starch and free sugars, could be interesting substrates (Table S2 and Table 3). Starchy residues have also high dry weight (Table S2) so that large quantities of high yield biomass could be easily moved towards the bioethanol plant. Nevertheless, the potential of ethanol per tonne of each byproduct has to be compared with the amount of residue available in the area of interest. For instance, although, as reported in Table S4, around $700 \mathrm{~kg} / \mathrm{ha}$ of ethanol could be obtained from the rice residues $(240.52,227.47,92.50,63.10,58.46,17.18 \mathrm{~kg} / \mathrm{ha}$ from rice husk, rice straw, broken rice, rice middlings, unripe rice, and discolored rice, respectively) rice wastes are not available in large amounts in the investigated area (around $1200 \mathrm{Mg}$ wet weight), and only up to $1400 \mathrm{Mg}$ of ethanol could be produced every year from rice byproducts (Table S5 and Figure 3).

Straws (barley, wheat, and soy) show promising potential alcohol yields (around $300 \mathrm{~kg} / \mathrm{Mg}$ of dry residues), and most interestingly, they have high yields per hectare (up to $800 \mathrm{~kg}$ of ethanol/ha, Figure 3, Table S4). Therefore, since in the studied area large extensions are cultivated with soybean and cereals, typical of the Po' Valley, high amounts of residues could be available to efficiently feed a bioethanol plant.

Overall, as reported in Table S5, about 73,000 Mg of bioethanol are potentially achievable using as feedstocks all the byproducts yearly available in the area considered in this study. The greatest shares of such ethanol come from cellulose (61.22\%) and hemicellulose $(29.60 \%)$ whereas limited contributions were calculated from simple sugars and starch (Table S5).

Taking into account both the available biomasses and the potential bioethanol obtainable from each substrate (Tables S2 and S4) more than 47,000 Mg of ethanol could be attained from the vine shoots and wheat straw. These substrates seem to be the most interesting bioethanol feedstocks among those evaluated in this study. Vineyards produce large quantities of vine shoots that are often left in the field as fertilizer or burnt to prevent phytopathogens [70]. In the area, leaving vine shoots in situ is uncommon because, when repeated, it could cause the development of pathogenic microorganisms and the accumulation of chemicals. As emerging from the interviews with farmers, most of the vine shoots are burned with serious environmental damages. Therefore, the use of this material for bioethanol production could be an innovative way to solve this old problem. In conclusion, the production of vine shoots was prudentially assumed to be $3 \mathrm{Mg}$ of material per hectare.Valorization of residues produced in the vine industry in the bioenergy and chemical sector is becoming an important issue: vineyard exhibits high potential since, as reported in Table S4, per each hectare, around $1300 \mathrm{~kg}$ of alcohol could be yearly obtained from vine shoots (1257.55), stalks (18.61), and grape marc (106.74). Thus, the utilization of residues from vineyards and wine manufacturing as feedstocks for bioethanol could be a profitable and sustainable opportunity for farmers.

Even if only low shares of ethanol could mainly derive from fruit or vegetable (Table S5), as reported above, the amount of these residues could strongly increase in years when large quantities of these residues are unsold or discarded for their low quality. Residues from the processing industries located in the area such as pear and apricot together with mixed fruits and chicory were also evaluated; although interesting in terms of potential ethanol for tonne of waste (Figure 2, Table S4) their contribution to the total 
potential ethanol is limited due to both their low availability in the area or their high water content (Figure 3).

To conclude, a second-generation biofuel production plant should be strategically located in an area where the feedstocks are available in adequate amounts all year long $[21,45,67]$. Furthermore, to reduce the expenses for transportation and storage they should be supplied from a maximum radius of $60-70 \mathrm{~km}$. Moreover, considering the high plant costs, previous studies demonstrated that the minimum capacity of a sustainable plant should be around $50,000 \mathrm{Mg}$ of ethanol per year [71]. Thus taken together, these results demonstrate the availability of sufficient feedstocks to sustain a bioethanol plant in the area under evaluation and could be used for a future technical evaluation to design a second-generation bioethanol production plant.

\section{Conclusions}

Although the European legislation targeted the opening of a huge market for secondgeneration bioethanol, in Europe industrial-scale bioethanol plants are not present yet. In 2015, Abengoa announced the exit from the cellulosic biofuel business and, three years later, the Beta Renewable's Crescentino Italian cellulosic ethanol plant closed. Both main European players in second-generation bioethanol reported multiple causes for departing cellulosic ethanol but the greatest hurdles were complex biomass supply and expensive pretreatment step [72]. Both challenges point at the lack of a model demonstrating the economic cost-effectiveness of the process. One of the bottlenecks is the proper identification and availability of the more suitable feedstocks to be used as substrates and their evaluation in terms of potential bioethanol yield.

In the Veneto Region, several private and public institutions show considerable interest in a project aimed at the construction of a second-generation bioethanol plant. The Veneto territory is located in a strategic logistic position characterized by a high agro-food vocation, by the presence of important industries, support facilities, and a good infrastructural system, which makes it extremely attractive for the location of new production plants [73]. As a consequence, the site where the future bioethanol production plant could be arranged was identified in the Municipality of Soave.

To the extent of our knowledge, for the first time, this research provides data for a future feasibility project of a pilot bioethanol plant at a local scale levelat least in Italy. The results of the study highlight that relatively large amounts of residual biomass of agricultural origin are available in the considered area. Since the main amounts of bioethanol could be obtained from cellulose and hemicellulose, these results are essential not only to select the best feedstocks but also to identify the most suitable pretreatments to convert these polymers into simple sugars. Moreover, some categories of wasted biomass can constitute a disposal problem for the production system: their transformation into valueadded products could lead to a reduction in removal costs and raise the profits of farmers. This approach could contribute to both valorize byproducts and increase the profitability of agricultural enterprises. Therefore, the recovery and exploitation of agricultural wastes for energy purposes could be an alternative solution to the disposal and an income opportunity for farmers, through the activation of short local chains and positive impact in rural areas.

Supplementary Materials: The following are available online at https://www.mdpi.com/2227-9 717/9/2/344/s1, Table S1: Crops and cultivated hectares in the analyzed area; Table S2. Yearly expected amounts of agricultural residues available in the analyzed area and their content in cellulose, hemicellulose, starch, lignin; Table S3: Fermentable sugars composition of each residue and yearly expected amounts of sugars $(\mathrm{Mg})$ in the analyzed area. Table S4. Potential ethanol yields (kg) per megagram of dry residue from starch, cellulose, hemicellulose, and fermentable sugars and potential ethanol $(\mathrm{kg})$ per each cropped hectare in the area of interest; Table S5. Yearly potential ethanol $(\mathrm{Mg})$ obtainable from the residues, from starch, cellulose, hemicellulose, and sugars. 
Author Contributions: Conceptualization, S.C., M.B., L.F., M.D., G.P.; methodology, S.C., M.B., L.F, M.D., G.P.; writing—original draft, M.B.; writing review and editing, S.C., L.F.; investigation, L.F., M.B., M.D., G.P., V.Z.; data curation, L.F., M.B., M.D., G.P., V.Z.; visualization, M.B., M.D., L.F., S.C.; supervision, S.C., M.B., L.F.; funding acquisition, S.C., M.B., L.F. All authors have read and agreed to the published version of the manuscript.

Funding: This work was funded by Biorivaluta- PSR Regione Veneto mis 124- DgrV 1604/2012 and the University of Padova through DOR2084579/20, DOR2087054/20, DOR1928058/19, DOR1827441/18, DOR1715524/17, BIRD187814/18.

Institutional Review Board Statement: Not applicable.

Informed Consent Statement: Not applicable.

Data Availability Statement: Data is contained within the article and supplementary material.

Acknowledgments: The Authors are grateful to Federico Fontana, MSc (University of Padova) for HPLC analysis and Daniela Cappello, MSc (University of Padova) for valuable technical support.

Conflicts of Interest: The authors declare no conflict of interest. The funders had no role in the design of the study; in the collection, analyses, or interpretation of data; in the writing of the manuscript, or in the decision to publish the results.

\section{References}

1. Brojanigo, S.; Parro, E.; Cazzorla, T.; Favaro, L.; Basaglia, M.; Casella, S. Conversion of Starchy Waste Streams into Polyhydroxyalkanoates Using Cupriavidus necator DSM 545. Polymers 2020, 12, 1496. [CrossRef]

2. Favaro, L.; Todorov, S.D. Bacteriocinogenic LAB Strains for Fermented Meat Preservation: Perspectives, Challenges, and Limitations. Probiotics Antimicrob. Proteins 2017, 9, 444-458. [CrossRef]

3. Favaro, L.; Basaglia, M.; Casella, S. Improving polyhydroxyalkanoate production from inexpensive carbon sources by genetic approaches: A review. Biofuels Bioprod. Biorefining 2019, 13, 208-227. [CrossRef]

4. Koutinas, A.A.; Vlysidis, A.; Pleissner, D.; Kopsahelis, N.; Garcia, I.L.; Kookos, I.K.; Papanikolaou, S.; Kwan, T.H.; Lin, C.S.K. Valorization of industrial waste and by-product streams via fermentation for the production of chemicals and biopolymers. Chem. Soc. Rev. 2014, 43, 2587-2627. [CrossRef]

5. Romanelli, M.G.; Povolo, S.; Favaro, L.; Fontana, F.; Basaglia, M.; Casella, S. Engineering Delftia acidovorans DSM39 to produce polyhydroxyalkanoates from slaughterhouse waste. Int. J. Biol. Macromol. 2014, 71, 21-27. [CrossRef]

6. Zhu, X.; Campanaro, S.; Treu, L.; Seshadri, R.; Ivanova, N.; Kougias, P.G.; Kyrpides, N.; Angelidaki, I. Metabolic dependencies govern microbial syntrophies during methanogenesis in an anaerobic digestion ecosystem. Microbiome 2020, 8, 1-14. [CrossRef]

7. Alibardi, L.; Green, K.; Favaro, L.; Vale, P.; Soares, A.; Cartmell, E.; Fernández, Y.B. Performance and stability of sewage sludge digestion under $\mathrm{CO}_{2}$ enrichment: A pilot study. Bioresour. Technol. 2017, 245, 581-589. [CrossRef] [PubMed]

8. Decker, S.R.; Brunecky, R.; Tucker, M.P.; Himmel, M.E.; Selig, M.J. High-Throughput Screening Techniques for Biomass Conversion. BioEnergy Res. 2009, 2, 179-192. [CrossRef]

9. Isah, S.; Ozbay, G. Valorization of Food Loss and Wastes: Feedstocks for Biofuels and Valuable Chemicals. Front. Sustain. Food Syst. 2020, 4, 1-13. [CrossRef]

10. Directive (EU) 2018/2001 of the European Parliament and of the Council of 11 December 2018 on the Promotion of the Use of Energy from Renewable Sources. Available online: https:/ / eur-lex.europa.eu/legal-content/EN/TXT/?uri=uriserv:OJ.L_.2018. 328.01.0082.01.ENG\&toc=OJ:L:2018:328:TOC (accessed on 9 January 2021).

11. Lynd, L.R. The grand challenge of cellulosic biofuels. Nat. Biotechnol. 2017, 35, 912-915. [CrossRef] [PubMed]

12. Radu, A.; Pana, C.; Negurescu, N. An experimental study on performance and emission characteristics of a bioethanol fuelled SI engine. UPB Sci. Bull. Ser. D 2014, 76, 193-200.

13. Saifuddin, N.; Refal, H.; Kumaran, P. Performance and emission characteristics of micro gas turbine engine fuelled with bioethanol-diesel-biodiesel blends. Int. J. Automot. Mech. Eng. 2017, 14, 4030-4049. [CrossRef]

14. Sweeney, M.D.; Xu, F. Biomass Converting Enzymes as Industrial Biocatalysts for Fuels and Chemicals: Recent Developments. Catalysts 2012, 2, 244-263. [CrossRef]

15. Karimi, K.; Chisti, Y. Future of bioethanol ... . Biofuel Res. J. 2015, 2, 147. [CrossRef]

16. Mussatto, S.I.; Dragone, G.; Guimarães, P.M.; Silva, J.P.A.; Carneiro, L.M.; Roberto, I.C.; Teixeira, J.A. Technological trends, global market, and challenges of bio-ethanol production. Biotechnol. Adv. 2010, 28, 817-830. [CrossRef] [PubMed]

17. Subramaniam, Y.; Masron, T.A.; Azman, N.H.N. Biofuels, environmental sustainability, and food security: A review of 51 countries. Energy Res. Soc. Sci. 2020, 68, 101549. [CrossRef]

18. Tomei, J.; Helliwell, R. Food versus fuel? Going beyond biofuels. Land Use Policy 2016, 56, 320-326. [CrossRef]

19. Pimentel, D.; Hess, R.; Diaz-Chavez, R.; Ravindranath, R.H.; Cortez, L.B. Food Versus Fuel: An Informed Introduction to Biofuels; Zed Books Ltd.: London, UK, 2013. 
20. Kumar, A. Climate Change: Challenges to Reduce Global Warming and Role of Biofuels. In Climate Change, Photosynthesis and Advanced Biofuels; Springer International Publishing: Singapore, 2020; pp. 13-54.

21. Susmozas, A.; Martín-Sampedro, R.; Ibarra, D.; Eugenio, M.E.; Iglesias, R.; Manzanares, P.; Moreno, A.D. Process Strategies for the Transition of $1 G$ to Advanced Bioethanol Production. Processes 2020, 8, 1310. [CrossRef]

22. Cagnin, L.; Favaro, L.; Gronchi, N.; Rose, S.H.; Basaglia, M.; Van Zyl, W.H.; Casella, S. Comparing laboratory and industrial yeast platforms for the direct conversion of cellobiose into ethanol under simulated industrial conditions. FEMS Yeast Res. 2019, 19, 018. [CrossRef] [PubMed]

23. Gronchi, N.; Favaro, L.; Cagnin, L.; Brojanigo, S.; Pizzocchero, V.; Basaglia, M.; Casella, S. Novel Yeast Strains for the Efficient Saccharification and Fermentation of Starchy By-Products to Bioethanol. Energies 2019, 12, 714. [CrossRef]

24. Galbe, M.; Zacchi, G. Pretreatment of Lignocellulosic Materials for Efficient Bioethanol Production. In Tissue Engineering III: Cell-Surface Interactions for Tissue Culture; Springer International Publishing: Berlin/Heidelberg, Germany, 2007; Volume 108, pp. $41-65$.

25. Vohra, M.; Manwar, J.; Manmode, R.; Padgilwar, S.; Patil, S. Bioethanol production: Feedstock and current technologies. J. Environ. Chem. Eng. 2014, 2, 573-584. [CrossRef]

26. Chopda, R.; Ferreira, J.A.; Taherzadeh, M.J. Biorefining Oat Husks into High-Quality Lignin and Enzymatically Digestible Cellulose with Acid-Catalyzed Ethanol Organosolv Pretreatment. Processes 2020, 8, 435. [CrossRef]

27. Ericsson, K.; Nilsson, L.J. Assessment of the potential biomass supply in Europe using a resource-focused approach. Biomass Bioenergy 2006, 30, 1-15. [CrossRef]

28. De Wit, M.; Faaij, A. European biomass resource potential and costs. Biomass Bioenergy 2010, 34, 188-202. [CrossRef]

29. United States Department of Energy; Perlack, R.D.; Eaton, L.M.; Turhollow, J.A.F.; Langholtz, M.H.; Brandt, C.C.; Downing, M.E.; Graham, R.L.; Wright, L.L.; Kavkewitz, J.M.; et al. US Billion-Ton Update: Biomass Supply for a Bioenergy and Bioproducts Industry; Oak Ridge National Laboratory: Oak Ridge, TN, USA, 2011.

30. Lauri, P.; Havlík, P.; Kindermann, G.; Forsell, N.; Böttcher, H.; Obersteiner, M. Woody biomass energy potential in 2050. Energy Policy 2014, 66, 19-31. [CrossRef]

31. Navarrete, C.; Jacobsen, I.H.; Martínez, J.L.; Procentese, A. Cell Factories for Industrial Production Processes: Current Issues and Emerging Solutions. Processes 2020, 8, 768. [CrossRef]

32. Bentsen, N.S.; Felby, C.; Thorsen, B.J. Agricultural residue production and potentials for energy and materials services. Prog. Energy Combust. Sci. 2014, 40, 59-73. [CrossRef]

33. García-Condado, S.; López-Lozano, R.; Panarello, L.; Cerrani, I.; Nisini, L.; Zucchini, A.; Van der Velde, M.; Baruth, B. Assessing lignocellulosic biomass production from crop residues in the European Union: Modelling, analysis of the current scenario and drivers of interannual variability. GCB Bioenergy 2019, 11, 809-831. [CrossRef]

34. Latimer, G.W. Official Methods of Analysis of AOAC International; AOAC International: Rockville, MD, USA, 2016; ISBN 978-0935584-87-5.

35. Van Soest, P.V.; Robertson, J.B.; Lewis, B.A. Methods for Dietary Fiber, Neutral Detergent Fiber, and Nonstarch Polysaccharides in Relation to Animal Nutrition. J. Dairy Sci. 1991, 74, 3583-3597. [CrossRef]

36. Favaro, L.; Cagnin, L.; Basaglia, M.; Pizzocchero, V.; Van Zyl, W.H.; Casella, S. Production of bioethanol from multiple waste streams of rice milling. Bioresour. Technol. 2017, 244, 151-159. [CrossRef]

37. Usenik, V.; Fabčič, J.; Štampar, F. Sugars, organic acids, phenolic composition and antioxidant activity of sweet cherry (Prunus avium L.). Food Chem. 2008, 107, 185-192. [CrossRef]

38. Spatari, S.; Bagley, D.M.; MacLean, H.L. Life cycle evaluation of emerging lignocellulosic ethanol conversion technologies. Bioresour. Technol. 2010, 101, 654-667. [CrossRef]

39. Godin, B.; Lamaudière, S.; Agneessens, R.; Schmit, T.; Goffart, J.P.; Stilmant, D.; Gerin, P.A.; Delcarte, J. Chemical characteristics and biofuel potential of several vegetal biomasses grown under a wide range of environmental conditions. Ind. Crops Prod. 2013, 48, 1-12. [CrossRef]

40. Huang, S.; Liu, T.; Peng, B.; Geng, A. Enhanced ethanol production from industrial lignocellulose hydrolysates by a hydrolysatecofermenting Saccharomyces cerevisiae strain. Bioprocess Biosyst. Eng. 2019, 42, 883-896. [CrossRef] [PubMed]

41. Mahboubi, A.; Ylitervo, P.; Doyen, W.; De Wever, H.; Molenberghs, B.; Taherzadeh, M.J. Continuous bioethanol fermentation from wheat straw hydrolysate with high suspended solid content using an immersed flat sheet membrane bioreactor. Bioresour. Technol. 2017, 241, 296-308. [CrossRef]

42. Yuan, Z.; Li, G.; Hegg, E.L. Enhancement of sugar recovery and ethanol production from wheat straw through alkaline preextraction followed by steam pretreatment. Bioresour. Technol. 2018, 266, 194-202. [CrossRef] [PubMed]

43. Cho, E.J.; Trinh, L.T.P.; Song, Y.; Lee, Y.G.; Bae, H.-J. Bioconversion of biomass waste into high value chemicals. Bioresour. Technol. 2020, 298, 122386. [CrossRef] [PubMed]

44. Myburgh, M.W.; Cripwell, R.A.; Favaro, L.; Van Zyl, W.H. Application of industrial amylolytic yeast strains for the production of bioethanol from broken rice. Bioresour. Technol. 2019, 294, 122222. [CrossRef]

45. Cripwell, R.A.; Favaro, L.; Viljoen-Bloom, M.; Van Zyl, W.H. Consolidated bioprocessing of raw starch to ethanol by Saccharomyces cerevisiae: Achievements and challenges. Biotechnol. Adv. 2020, 42, 107579. [CrossRef]

46. Favaro, L.; Basaglia, M.; Saayman, M.; Rose, S.H.; Van Zyl, W.H. Engineering amylolytic yeasts for industrial bioethanol production. Chem. Eng. Trans. 2010, 20, 97-102. 
47. Favaro, L.; Basaglia, M.; Van Zyl, W.H.; Casella, S. Using an efficient fermenting yeast enhances ethanol production from unfiltered wheat bran hydrolysates. Appl. Energy 2013, 102, 170-178. [CrossRef]

48. Favaro, L.; Viktor, M.J.; Rose, S.H.; Viljoen-Bloom, M.; van Zyl, W.H.; Basaglia, M.; Cagnin, L.; Casella, S. Consolidated bioprocessing of starchy substrates into ethanol by industrial Saccharomyces cerevisiae strains secreting fungal amylases. Biotechnol. Bioeng. 2015, 112, 1751-1760. [CrossRef]

49. Suttie, J.M. Hay and Straw Conservation: For Small-Scale Farming and Pastoral Conditions; FAO: Rome, Italy, 2000; ISBN 92-5-104458-9.

50. Karlen, D.L.; Varvel, G.E.; Johnson, J.M.F.; Baker, J.M.; Osborne, S.L.; Novak, J.M.; Adler, P.R.; Roth, G.W.; Birrell, S.J. Monitoring Soil Quality to Assess the Sustainability of Harvesting Corn Stover. Agron. J. 2011, 103, 288-295. [CrossRef]

51. Wilhelm, W.W.; Johnson, J.M.F.; Karlen, D.L.; Lightle, D.T. Corn Stover to Sustain Soil Organic Carbon Further Constrains Biomass Supply. Agron. J. 2007, 99, 1665-1667. [CrossRef]

52. Aditiya, H.; Mahlia, T.; Chong, W.; Nur, H.; Sebayang, A. Second generation bioethanol production: A critical review. Renew. Sustain. Energy Rev. 2016, 66, 631-653. [CrossRef]

53. Hassan, S.S.; Williams, G.A.; Jaiswal, A.K. Emerging technologies for the pretreatment of lignocellulosic biomass. Bioresour. Technol. 2018, 262, 310-318. [CrossRef] [PubMed]

54. Sun, Y.; Cheng, J. Hydrolysis of lignocellulosic materials for ethanol production: A review. Bioresour. Technol. 2002, 83, 1-11. [CrossRef]

55. Akbas, M.Y.; Stark, B.C. Recent trends in bioethanol production from food processing byproducts. J. Ind. Microbiol. Biotechnol. 2016, 43, 1593-1609. [CrossRef] [PubMed]

56. Izmirlioglu, G.; Demirci, A. Strain selection and medium optimization for glucoamylase production from industrial potato waste by Aspergillus niger. J. Sci. Food Agric. 2015, 96, 2788-2795. [CrossRef]

57. Mosier, N.S. Cellulosic ethanol—Biofuel beyond corn. In Bioenergy; Dahiya, A., Ed.; Academic Press: Cambridge, MA, USA, 2020; pp. 217-221.

58. Khan, T.S.; Mubeen, U. Wheat straw: A pragmatic overview. Curr. Res. J. Biol. Sci. 2012, 4, 673-675.

59. Ursachi, V.-F.; Gutt, G. Production of Cellulosic Ethanol from Enzymatically Hydrolysed Wheat Straws. Appl. Sci. 2020, 10, 7638. [CrossRef]

60. Senila, L.; Neag, E.; Torok, I.; Cadar, O.; Kovacs, E.; Tenu, I.; Roman, C. Vine shoots waste-New resources for bioethanol production. Rom. Biotechnol. Lett. 2020, 25, 1253-1259. [CrossRef]

61. Hahn-Hägerdal, B.; Karhumaa, K.; Fonseca, C.; Spencer-Martins, I.; Gorwa-Grauslund, M.F. Towards industrial pentosefermenting yeast strains. Appl. Microbiol. Biotechnol. 2007, 74, 937-953. [CrossRef] [PubMed]

62. Chu, B.C.; Lee, H. Genetic improvement of Saccharomyces cerevisiae for xylose fermentation. Biotechnol. Adv. 2007, 25, 425-441. [CrossRef]

63. Tran, P.H.N.; Ko, J.K.; Gong, G.; Um, Y.; Lee, S.-M. Improved simultaneous co-fermentation of glucose and xylose by Saccharomyces cerevisiae for efficient lignocellulosic biorefinery. Biotechnol. Biofuels 2020, 13, 12-14. [CrossRef] [PubMed]

64. Liu, T.; Huang, S.; Geng, A. Recombinant Diploid Saccharomyces cerevisiae Strain Development for Rapid Glucose and Xylose Co-Fermentation. Fermentation 2018, 4, 59. [CrossRef]

65. Cunha, J.T.; Soares, P.O.; Romaní, A.; Thevelein, J.M.; Domingues, L. Xylose fermentation efficiency of industrial Saccharomyces cerevisiae yeast with separate or combined xylose reductase/xylitol dehydrogenase and xylose isomerase pathways. Biotechnol. Biofuels 2019, 12, 20. [CrossRef] [PubMed]

66. Ko, J.K.; Um, Y.; Woo, H.M.; Kim, K.H.; Lee, S.-M. Ethanol production from lignocellulosic hydrolysates using engineered Saccharomyces cerevisiae harboring xylose isomerase-based pathway. Bioresour. Technol. 2016, 209, 290-296. [CrossRef]

67. Favaro, L.; Jansen, T.; van Zyl, W.H. Exploring industrial and natural Saccharomyces cerevisiae strains for the bio-based economy from biomass: The case of bioethanol. Crit. Rev. Biotechnol. 2019, 39, 800-816. [CrossRef]

68. Cao, L.; Yu, I.K.; Liu, Y.; Ruan, X.; Tsang, D.C.; Hunt, A.J.; Ok, Y.S.; Song, H.; Zhang, S. Lignin valorization for the production of renewable chemicals: State-of-the-art review and future prospects. Bioresour. Technol. 2018, 269, 465-475. [CrossRef]

69. Negi, H.; Singh, R.K. A review on lignin utilization in petroleum exploration, petroleum products formulation, bio-fuel production, and oil spill clean-up. Biomass Convers. Biorefinery 2020, 1-12. [CrossRef]

70. Gullón, P.; Gullón, B.; Dávila, I.; Labidi, J.; Gonzalez-Garcia, S. Comparative environmental Life Cycle Assessment of integral revalorization of vine shoots from a biorefinery perspective. Sci. Total. Environ. 2018, 624, 225-240. [CrossRef] [PubMed]

71. Bojic, S.; Martinov, M.; Brcanov, D.; Djatkov, D.; Georgijevic, M. Location problem of lignocellulosic bioethanol plant-Case study of Serbia. J. Clean. Prod. 2018, 172, 971-979. [CrossRef]

72. Dale, B. Time to Rethink Cellulosic Biofuels? Biofuels Bioprod. Biorefining 2018, 12, 5-7. [CrossRef]

73. Regione del Veneto. 10 June 2011—Palazzo Balbi, Venice-Regional Transport System of Veneto: An Overview. Available online: https:/ / www.regione.veneto.it/web/programmi-comunitari/dalla-a-alla-z-dettaglio?_spp_detailld=122806 (accessed on 9 January 2021). 